NO.10 Journal of Petroleum Research \& Studies ( JPR \& S)

\title{
Emulsion Breaking of Used Cutting Fluid by Electrocoagulation Method to Decrease Water Pollution
}

Laith Hamzah Thuaban; Hiba Mahmmuod Yas; Faris muoayad Ahmed

\section{$\underline{\text { Abstract }}$}

Cutting fluids are liquids having different compositions that are used in metal possessing operations. After being used, the fluids became less effective and need to be changed. In this research the treatment of petroleum oil emulsion type cutting fluid has been carried out using electrocoagulation technology to decrease its environmental impact on water resources. Cutting oil type 7201 produced in (Aldaura) refinery has been treated at different concentrations $(1,2,3$ and $4 \%)$ by weight to study the effect of the cutting fluid concentration on the time needed for emulsion breaking. The effect of other parameters such as electrical voltage (by using 40, 50 and 60 volt), aluminum metal electrodes' surface area (by using 4 and $6 \mathrm{~cm}^{2}$ ) and the effect of added $\mathrm{NaCl}$ salt concentrations (by using 0.2, 0.27 and $0.33 \%$ by weight) on the emulsion breaking time has been studied. It has been found that there is an optimum voltage for each emulsion concentration and the emulsion breaking time increase with the increase of the cutting fluid concentration and it decrease with the increase of the electrode surface area and the salt concentration.

Keyword: Emulsion breaking, Cutting fluid, Electrocoagulation, Water pollution. 
سوائل القطع هي عبارة عن سوائل ذات تر اكيب وتر اكيز مختلفة وتستعمل في عمليات تشكيل المعادن لتقليل الاحتكالك و التبريد وبعد مرور فترة زمنية معينة على الاستعمال تصبح هذه السوائل اقل كفاءة وتحتاج

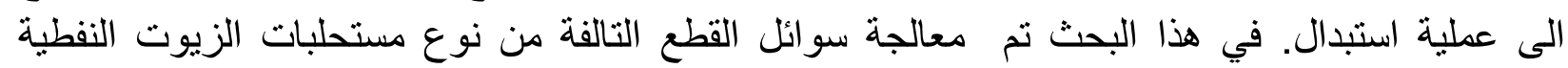
باستعمال تقتية التخثير الكهربائي لتقليل تاثير ها السيء على البيئة المائية وقد تم استعمال المستحلبات الناتجة من زيت القطع 7201 المنتج في مصافي الدورة وبتر اكيز وزنية مختلفة (1,2,3,4\% ) لدئية لدراسة تأثير تركيز المستحلب الزيت النفطي على الزمن المطلوب لكسر الاستحلاب كما تم دراسة عوامل اخرى مثل تغير فرق الجهد المسلط (الفولتية الكهربائية )عند استعمال فرق جهد(40,50,60 ) فولت ودراسة تاتثير المساحة السطحية للاقطاب الالمنيوم باستعمال اقطاب بمساحة (4,6cm² المضافة \% (0.3,0.27,0.33) على زمن كسر الاستحلاب .لقد وجد ان هناك فرق جهد مسلط معين هو الافضل لكل تركيز من المستحلبات وان زمن زمن كسر الاستحلاب يزداد بزيادة تركيز الزيت النفطي المستحلب ويقل بزيادة كمية الاملاح في المستحلب وزيادة المساحه السطحية.

$$
\text { الكلمات المفتاحيه : كسر الاستحلاب ,زيوت القطع ,التخثير الكهربائي ,ثلوث المياه. }
$$

\section{Introduction}

Cutting fluids are liquids having different compositions that are used in metal possessing operations. Cutting fluid pumps over the cutting site of machines such as lathes, milling machines, shapers and saws for cooling the tool, work piece and chips or for lubricating. A variety of cutting fluids are available to satisfy the requirements of machining processes. The four basic types of cutting fluids are as follows: Straight oils, synthetic fluids, semi-synthetic fluids and emulsified cutting fluid which are the largest type of cutting fluids [1].

After being used the fluids become less effective because of their thermal degradation and contamination by substances in suspension therefore they must be replaced periodically, generating a waste stream called spent cutting oil [1]. The environmental impact of metal working wastes can be acute. Heavy metals, acids, surfactants and oils are all highly toxic to aquatic life. Serious stream degradation results from the direct discharge of insufficiently treated metal wastes. 


\section{NO.10 Journal of Petroleum Research \& Studies ( JPR \& S)}

Oils in drinking water sources cause objectionable taste, odours, turbidity, film and making filtration treatment difficult. Bioassay data indicate that oil is toxic to fish. In greater quantities, it limits oxygen transfer, hindering biological activity [2]. It is desirable then to separate the oil phase from the water phase, in order to minimize the disposal costs and to minimize the negative impact of fluid disposal on the environment [3]. In general, no single treatment process or commercial device will remove all forms of oil (free, emulsified or dissolved) in oil-water mixtures. The most commonly used method to break the emulsion is chemical treatment (chemical addition) [4].

The breaking of emulsions is necessary in many industrial operations; millions of dollars are being spent each year in preventing or breaking an emulsion.

Emulsion breaking can be very complex, because no two emulsions are alike. Even emulsions from a single source can vary over time. The result is that emulsion breakers, or demulsifiers, must be selected, and even formulated on a case-by-case basis [5]. The treatment of oily wastewater is normally divided into two steps:

1- Coagulation: This is destruction of the emulsifying properties of the surface active agent or neutralization of the charged oil droplet. In municipal drinking water treatment coagulation is the process of adding chemicals to water to make dissolved and suspended particles bind together, forming larger particles that will settle out of the water as sludge [6].

2- Coalescence: This is agglomeration of the neutralized droplets into large, separable globules. 


\section{NO.10 Journal of Petroleum Research \& Studies ( JPR \& S)}

\section{Electrocoagulation process:}

Electrocoagulation is the introduction of an electrical charge in a wastewater stream using suitable type of electrodes made of iron or aluminum in order to coagulate and precipitate the pollutants. Some of the electrode will dissolve (become ionized) in solution. In this way, and only this way, EC resembles chemical coagulation - in that iron or aluminum ions, for instance, may be introduced into the solution to be treated [7]. This electrochemical process results in a sludge that can either float or sink depending on the specific gravity.

Electrocoagulation requires simple equipment and is easy to operate with sufficient operational latitude to handle most problems encountered on running Wastewater treated by electrocoagulation gives palatable, clear, colorless and odorless water.

The electrocoagulation process avoids uses of chemicals and so there is no problem of neutralizing excess chemicals and no possibility of secondary pollution caused by chemical substances added at high concentration as when chemical coagulation of wastewater is used

An electrocoagulation cell (reactor) consists of an anode and cathode between which the wastewater is pumped. Most systems use DC current where electrode plates are sacrificed (dissolved into solution) causing increased high metal concentrations that end up as oxide precipitates [7] .This process has had success in other industries in recovering suspended and dissolved solids, as well as breaking oily emulsions. One of the more widespread applications of the technology has been used to remove metal ions from electroplating wastewater streams. 


\section{NO.10 Journal of Petroleum Research \& Studies ( JPR \& S)}

The aim of this research is to study the effectiveness of the electrocoagulation process in the treatment of spent cutting fluid and to study the parameters affecting the process. A second objective was to assess the influence of the variables on the treatment effectiveness.

\section{Experimental work and procedure:}

This research is mainly focused on the electrocoagulation treatment of cutting oil emulsions with different (relatively) high concentrations $(4,3,2$ and $1 \%$ by weight) to investigate the effects of the main operating parameters such as oil concentration, electric voltage, electrodes; surface area and dissolved salts concentration on emulsion breaking time.

\section{Preparation of oil emulsion:}

Oil-water emulsions were prepared from cutting oil 7201 produced in Al-Daura refinery and used for drilling and machining operations in Iraqi manufacturing plants. The $4 \%$ by wt. emulsion was prepared by adding 6 gm of cutting oil to 144 gm of deionized water (as recommended by oil manufacturers) followed by mixing for 5 minutes by using mechanical stirrer (Citeneo) at $1500 \mathrm{rpm}$ to form very stable emulsion. This method was used to prepare other concentrations of cutting fluid (3, 2 and $1 \%$ by weight) respectively.

\section{Breaking the emulsion of 7201 cutting fluid using electrocoagulation cell:}

The breaking of the emulsion was carried out using electrocoagulation cell as shown in figure (1), it consists of cylindrical reactor of $250 \mathrm{ml}$ volume and two electrodes of aluminum one as an anode and the other as cathode these electrodes were connected to a DC power supply (Reo Boris Van Wolff) having an input of 220 volt and variable out put of (0 to 250) volt with a maximum current of (25) amp. The power supply has two indicators for the measurement of voltage and 


\section{NO.10 Journal of Petroleum Research \& Studies ( JPR \& S)}

current passing through the cell. All experiments were carried out at room temperature near $25{ }^{\circ} \mathrm{C}$, and to avoid passivation of the electrodes, the electrochemical cell was entirely cleaned after each experiment with detergent [8].

Deferent voltages were used (40,50 and 60 volt) to study the effect of voltage on emulsion breaking time and Different aluminum electrodes surface area (4 and 6 $\left.\mathrm{cm}^{2}\right)$ with dimensions of $(30 \mathrm{~mm} \times 20 \mathrm{~mm} \times 1 \mathrm{~mm})$ and $(20 \mathrm{~mm} \times 20 \mathrm{~mm} \times 1 \mathrm{~mm})$ were used to study the effect of electrodes surface area on emulsion breaking time, In order to increase the conductivity of the solution, sodium chloride was added to the solution and mixed for one minutes using magnetic stirrer before injecting it into the cell. The chloride salt added to the solution can also prevent the formation of oxide layer on the anode and therefore reduce the passivation problem of the electrode.

The electrochemical reaction occurring at the anode is expressed by the following equations [2]:

$\mathrm{Al}(\mathrm{s}) \rightarrow \mathrm{Al}^{+3}(\mathrm{aq})+3 \mathrm{e}^{-}$

Hydrogen evolution occurs at the cathode

$2 \mathrm{H}_{2} \mathrm{O}(\mathrm{l})+2 \mathrm{e}^{-} \rightarrow \mathrm{H}_{2}(\mathrm{~g})+2 \mathrm{OH}^{-}(\mathrm{aq})$

$2 \mathrm{H}(\mathrm{aq})++2 \mathrm{e}-\longrightarrow \mathrm{H}_{2}(\mathrm{~g})$

The generated $\mathrm{Al}^{+3}$ (aq) ions react with water and hydroxyl ions to form corresponding hydroxydes and/or polyhydroxides as follow:

$\mathrm{Al}^{+3}(\mathrm{aq})+2 \mathrm{H}_{2} \mathrm{O} \rightarrow \mathrm{Al}(\mathrm{OH})_{2}+2 \mathrm{H}^{+}$

$\mathrm{Al}(\mathrm{OH})_{2}+\mathrm{H}_{2} \mathrm{O} \rightarrow \mathrm{Al}(\mathrm{OH})_{2}+2 \mathrm{H}^{+\cdots}$ 
$\mathrm{Al}(\mathrm{OH})_{2}+\mathrm{H}_{2} \mathrm{O} \rightarrow \mathrm{Al}(\mathrm{OH})_{3}+\mathrm{H}^{+}$

$$
\mathrm{Al}(\mathrm{OH})_{3}+\mathrm{H}_{2} \mathrm{O} \rightarrow \mathrm{Al}(\mathrm{OH})_{4}+\mathrm{H}^{+}
$$

After setting the current and the space between the electrodes and salt quantity the experiment initiate and the time required to break the emulsion is determined by visual observation of the change in turbidity and the evaluation of the emulsion breaking was based on the volume of the separated oil layer.

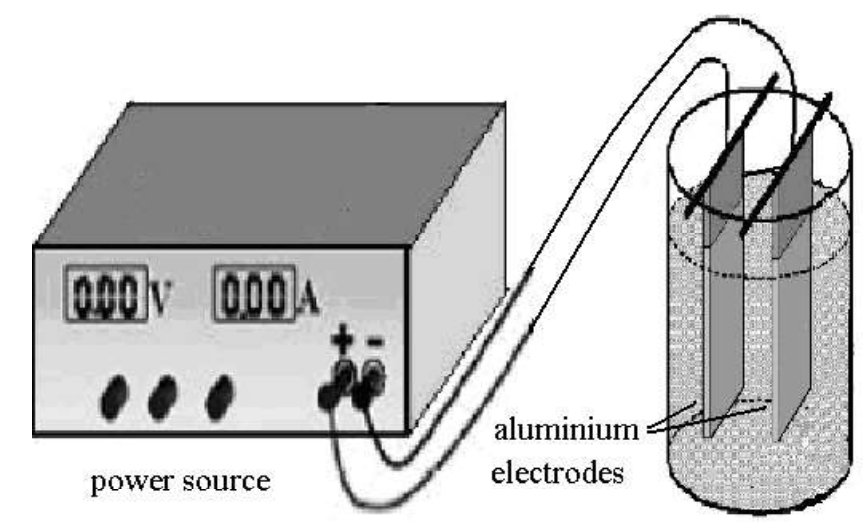

Fig. (1) The cell used for breaking the emulsion of 7201 cutting fluid

\section{Results and discussion}

In order to examine the efficiency of electrocoagulation process for breaking emulsion several operating parameters such as initial emulsified oil concentration, applied voltage, electrodes surface area, and sodium chloride concentration have been explored. 
1-The effect of initial emulsified oil concentration on the emulsification breaking time

To study the effect of initial emulsified oil concentration on separation time different emulsion concentrations have been made (1, 2, 3 and $4 \%$ by weight) and the experiments were carried out using different voltages. Figure (2) shows the effect of emulsion concentration when using 40, 50 and 60 volt.

The experiments has proved that the increase in the oil concentration will increase the emulsion breaking time because the increase in the oil concentration will lead to an increase in the number of the aluminum ions required for coalescence of emulsified oil droplets to produce larger oil droplets that enhance the separation of these droplets from the water phase as floating layer and that process called emulsification breaking.

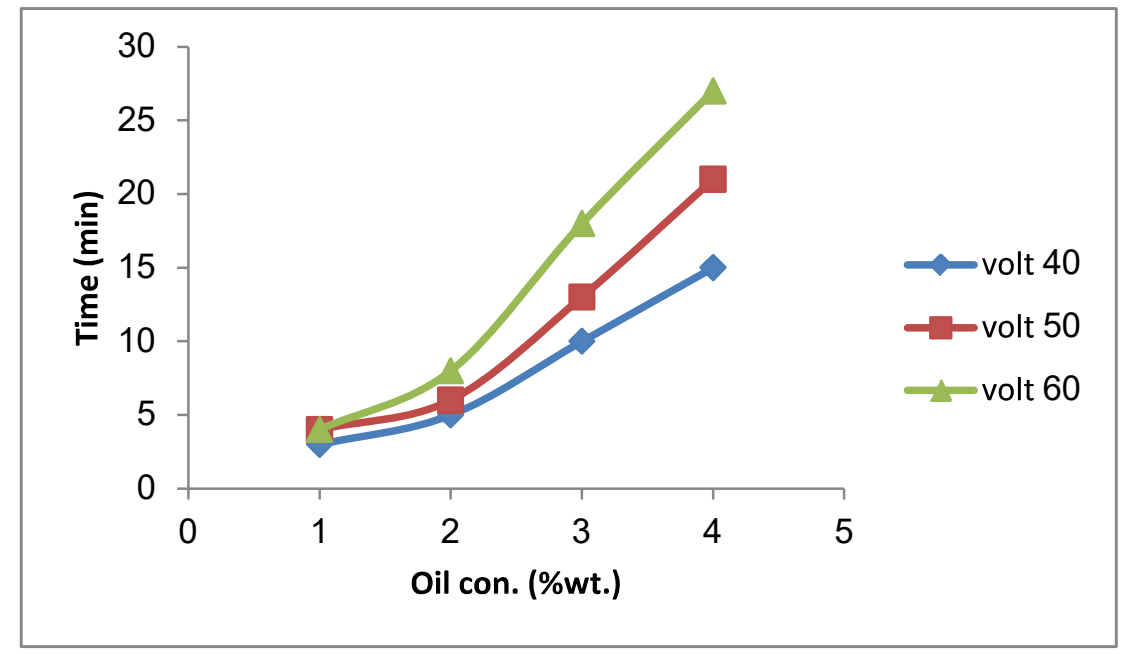

Fig (2) The effect of emulsion concentration when using different voltages 


\section{NO.10 Journal of Petroleum Research \& Studies (JPR \& S)}

\section{2- The effect of electric voltage on emulsification breaking time}

In electrocoagulation the electrodes of the electrochemical cell are connected to an electrical power source, the relationship between current density $\left(\mathrm{A} / \mathrm{cm}^{2}\right)$ and the amount of aluminum which goes into solution $\left(\mathrm{g} \mathrm{Al} \mathrm{cm}^{-2}\right)$ can be calculated by using faraday's law [6]:

$$
\mathrm{w}=\mathrm{it} \mathrm{M} / \mathrm{zF}
$$

Where:

$\mathrm{w}=$ aluminum dissolving $\left(\mathrm{g} / \mathrm{cm}^{2}\right)$.

$\mathrm{I}=$ current density $\left(\mathrm{A} / \mathrm{cm}^{2}\right)$.

$\mathrm{t}=$ time (s).

$\mathrm{M}=$ molecular weight of $\mathrm{Al}(\mathrm{m}=27)$. $\mathrm{g} / \mathrm{mol}$.

$\mathrm{Z}=$ number of electrodes involved in the oxidation reduction reaction $(\mathrm{z}=2)$.

$\mathrm{F}=$ Faraday's constant $(96486 \mathrm{C} / \mathrm{mol})$

To study the effect of electric voltage on emulsion breaking time, different voltages have been used (30,40,50, and 60 volt) the experiment showed that the breaking time needed when using $30 \mathrm{~V}$ was $25 \mathrm{~min}$ and this time decreases to 15 min. when using $40 \mathrm{~V}$ and the reason is that the increase in voltage led to an increase in the current which produced more dissolved aluminum ions that enhanced the coalescence of emulsified oil droplets, but the emulsion breaking time increased to $21 \mathrm{~min}$. when the applied voltage was 50 volt and increased to 27 min. When the applied voltage increased to 60 volt and the reason is that the more applied voltage will lead to the formation of more hydroxyl ions eq.(2) which lead to the formation of aluminum complexes eqs. $(4,5,6,7)$ rather than Aluminum ions which are responsible for the emulsion breaking, also the increase in the 
applied voltage leads to increase in the emulsion temperature that leads to the formation of whirlpools in the mixture that enhance the mixing between the oil droplets and water molecules which contradicts the emulsification breaking process and lead to an increase in the emulsion breaking time needed figure (3) .

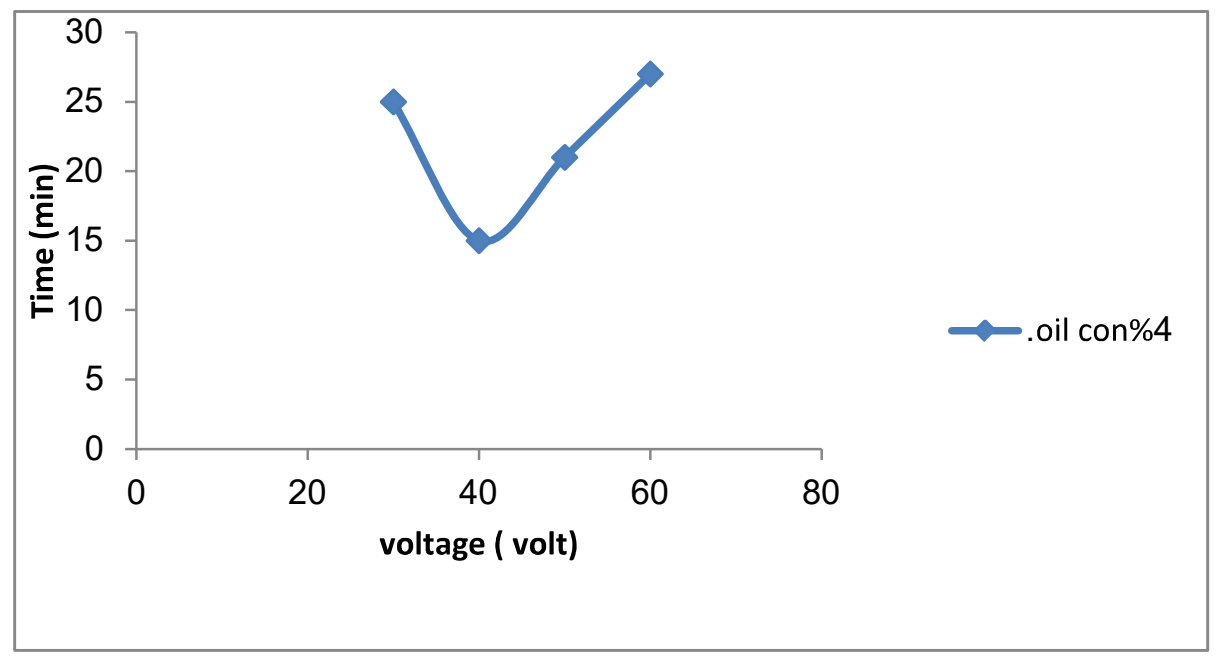

Fig. (3): Shows the effect of electric voltage on emulsification breaking time

\section{3 - The effect of electrodes' surface area on emulsification breaking time:}

Two electrodes sizes of aluminum were used to investigate their effect on the electrocoagulation efficiency. The results are shown in a figure (4) which indicates that by increasing the active area from $\left(4\right.$ to $\left.6 \mathrm{~cm}^{2}\right)$ the emulsion breaking time will be enhanced and the treatment time required will be reduced.

The experiments showed that the increase in the electrodes' surface area will decrease the time needed for emulsion breaking when using constant oil concentrations because that the increase in the electrodes' surface area will lead to generate more aluminum ions from the electrodes due to electric current that 
passes through the emulsion, these ions enhance the coalesces and decrease the emulsion breaking time.

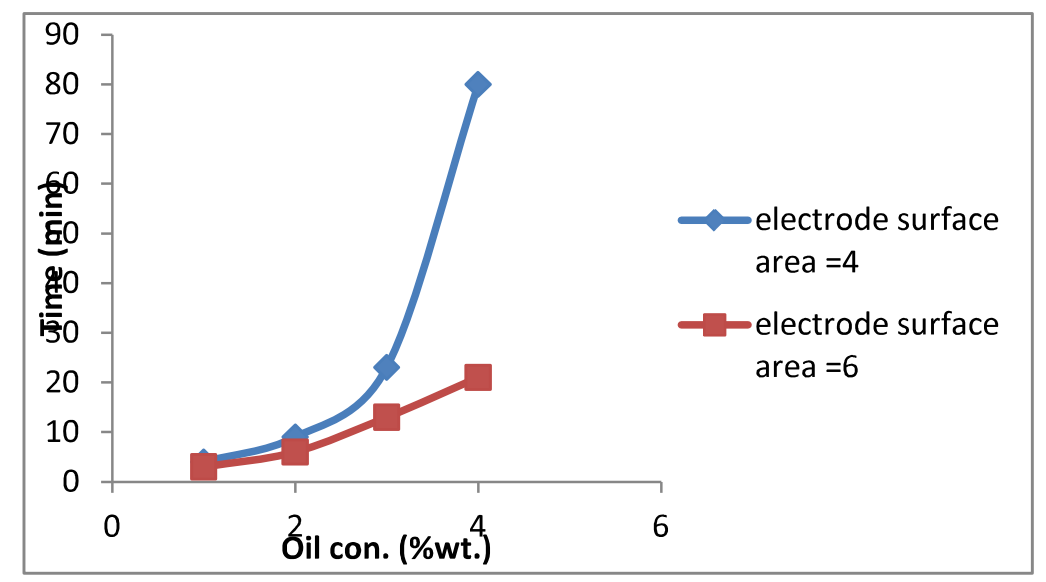

Fig. (4) Effect of surface area on the time needed for emulsion breaking

4 - The effect of the dissolved salts ratio on emulsification breaking time:

To study the effect of sodium chloride $(\mathrm{NaCl})$ salt concentrations on the emulsion breaking time different quantities of salts have been used $(0.3,0.4$, and 0.5$)$ grams of $\mathrm{NaCl}$ was added to each experiment which corresponds to $(0.2,0.27$ and $0.33 \%$ by weight). Sodium chloride was added for conductivity increasing and to avoid anode passivation, (which would result in current being expended to generate oxygen rather than dissolve iron), and salt addition helps to increase the conductivity of the wastewater, thereby reducing power consumption. As shown in figure (5) the experiments have proved that the increase of the dissolved salts ratio leads to a decrease in the emulsion breaking time at constant emulsion concentration and the reason for this case is that the increase in the dissolved salts ratio leads to increase in the electrical conductivity of the emulsion and that will increase the electric current that passes through the electrodes and generates more aluminum ions in the mixture that decreases the emulsification breaking time. 


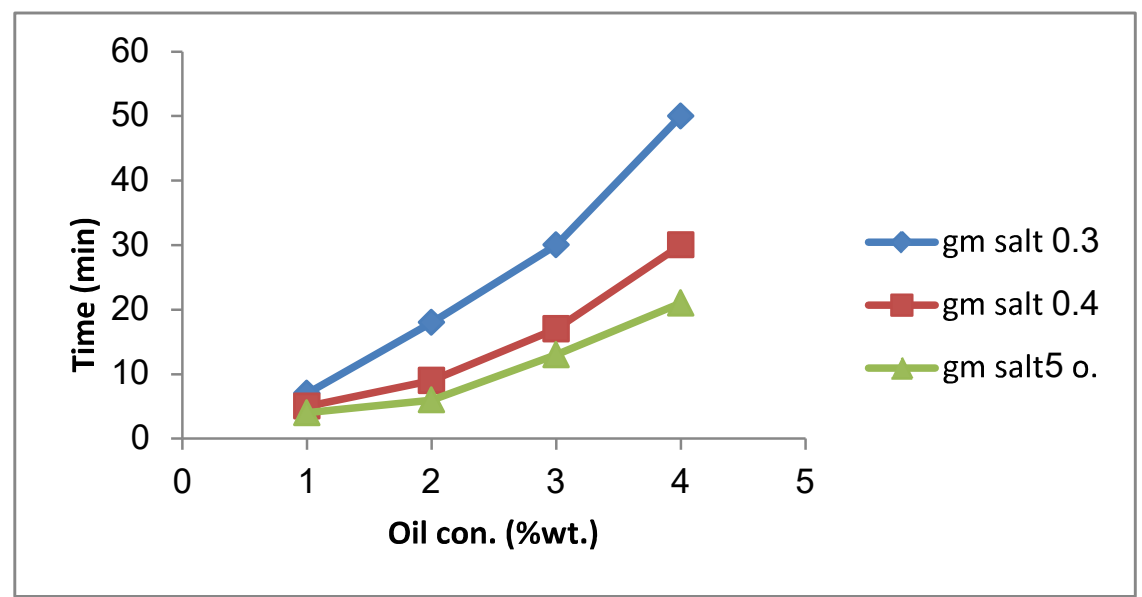

Fig. (5) Effect of dissolved salts ratio on emulsification breaking time

\section{Conclusion}

Electrocoagulation using aluminum electrodes is a feasible process for treatment of very stable cutting oil emulsions. The emulsion breaking decreased upon increasing initial concentration because the increase in the oil concentration will lead to an increase in the number of the aluminum ions required for coalescence of emulsified oil droplets. Aluminum concentration is controlled by adjusting the voltage in the electrocoagulation process due to the pronounce effect the current has on the treatment of the oily wastewater. It is also the most convenient variable to control. The effect of salinity was a major parameter on the current required to accomplish the emulsion breaking. With respect to the electrode size, the best removal obtained by using the electrode with the highest surface area due to the release of more aluminum ions. 


\section{References}

1. José Manuel Benito, Guillermo Ríos, Enrique Ortea, Eva Fernández, Angel Cambiella, Carmen Pazos, José Coca", Design and construction of a modular pilot plant for the treatment of oil-containing wastewaters", Elsevier Science B.V. Desalination, (2002).

2. Abid Baig, Mohsin Mir, Zafar I. Bhatti, Baig M A.; "removal of oil and grease from industrial effluents ", Electronic Journal of Environmental, Agricultural and Food Chemistry, (2004).

3. Ian MacPherson, Richard Edward Kuhlman, Michael J. Milo," Emulsifier/demulsifier system", (2005).

4. Dennis TV. Brinkman "emulsified industrial oils recycling" U. S Department of Energy Division of Industrial Energy Conservation, April (1982).

5. Champion technologies; "Emulsion breakers", www.champ-tech.com. (2008).

6. Ahmed A-Mohammed, Electrocoagulation of phenol for wastewater treatment, Iraqi Journal of Chemical and Petroleum Engineering, Vol.9 No.3 (December 2007) 37-41

7. Mickley; "Pretreatment Capabilities and Benefits of Electrocoagulation", Michael Mickley \& Associates, Boulder, Colorado (2004).

8. Kobya M., Can O.T., Bayramoglu M.; "Treatment of textile wastewaters by electrocoagulation using iron and aluminum electrodes", J. Hazard. Mater.B $100163-178,(2003)$. 